\section{Professor Ochir Gerel - A Profile}

\section{IUGS Vice-President}

Ochir Gerel graduated in geology with a specialization in petrology at the Charles University in Prague, Czech Republic, where she received her BSc and MSc degrees. She defended her $\mathrm{PhD}$ degree in petrology in 1978 at the Institute of Earth Crust, Siberian Branch of the Russian Academy of Science, Irkutsk, on the topic "Petrology and geochemistry of

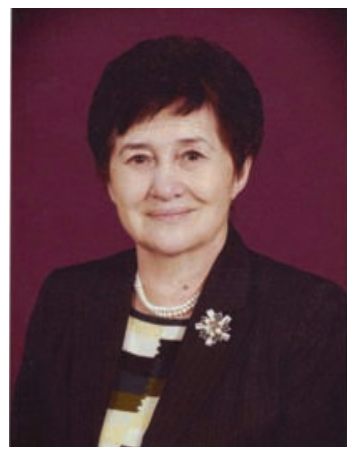

the pegmatite-bearing Mesozoic granites, Eastern Mongolia", and earned a D.Sc degree in geochemistry in 1990 at the Institute of Geochemistry, Russian Academy of Science, in geochemistry, on the topic "Petrology, geochemistry and metallogeny of subalkaline Mesozoic magmatism in Mongolia”.

Since 1965 she has been working as a Lecturer, Associate Professor, Full Professor, and Head (1978-2008) of the Department of geology at the Mongolian University of
Science. In 2000 she established Geoscience Center at the University and has since then been the Director of this Center. At the university O. Gerel was a PhD Council head, Joint D.Sc Council member and member of the Scientific Council. She has catalyzed wide international cooperation. She has led 14 international and 12 domestic projects, including "Mineral Resources, metallogenesis and tectonics of NE Asia", "Tectonics and geodynamics of North East Asia", "Global Mineral Resources Assessment", "GIS granitoids database of Mongolia", "Granitoid magmatism and metallogeny in Mongolia"; TACIS-TEMPUS projects "Curriculum development in Geology and Mining", "Teacher training in Geology and Mining", and others, and now is a leader of 4 International projects related to granitoid study, metallogenesis and the environment. During the past 30 years, she established and developed geosciences education in Mongolia, being a head of the Department of Geology.

O. Gerel has been active as a leader and as member of many professional geological organizations: Mongolian Geological Association, Mongolian Stratigraphic Commission, Mongolian Women Geoscientists, IAGOD Councillor and leader of Mongolian National IAGOD Group, IAGC, AGID, IGCP (2004-2011), and National
IYPE initiative. She is editor and co-editor of some twenty books, author of 25 scientific reports, five textbooks, and 280 scientific papers, editor of professional journals: Mongolian Geoscientist, Geology (Mongolia), Resource Geology (Japan), speaker at more than 70 international Geological Congresses and Symposia. She has led a number of international geological excursions, and organized many international symposia and workshops in Mongolia, many in cooperation with mining companies. O. Gerel initiated the SEG Student Chapter at the Mongolian University of Science \& Technology in cooperation with Ivanhoe Mines Mongolia. She worked as a visiting professor and researcher at several foreign universities, and supervised $25 \mathrm{PhD}$ students.

O. Gerel was awarded the Honored Scientist of Mongolia (2009), highest award of the Mongolian Universities Consortium (2001), Mongolian University of Science and Technology award for research (1996, 1999, 2000), Honor Geologist of the Mongolian Geology (1981), Honor Teacher of Mongolian Education (1990), Honor Scientist of Mongolian Science (1995), and the Mongolian Orders and Medails.

Address:

Mongolian University of Science \&

Technology, Department of Geology, Geoscience Center, P.O. 46, Box 520,

Baga Toiruu 34, 210646 Ulaanbaatar, Mongolia

Tel: 976-11-326425; Mob: 976-99121226

E-mail:gerel@must.edu.mn 